\title{
Financial Performance Analysis of Motilal Oswal Financial Services Ltd (MOFSL)
}

\author{
Sonia Lobo ${ }^{1} \&$ Ganesh Bhat S. ${ }^{2}$ \\ ${ }^{1}$ Research Scholar, College of Management \& Commerce, Srinivas University, Mangalore, \\ India \& Assistant Professor, Department of Humanities, NMAM Institute of Technology, \\ Nitte, India. \\ OrcidID: 0000-0002-8177-8855; E-mail: lobo14.sonia@gmail.com \\ ${ }^{2}$ Research Professor, College of Management \& Commerce, Srinivas University, Mangalore, \\ India. \\ OrcidID: (0000-0003-1950-8536); E-mail: ganbhatbvr@ rediffmail.com
}

Area of the Paper: Business Management.

Type of the Paper: Research Case Study.

Type of Review: Peer Reviewed as per $|\mathrm{C}| \mathrm{O}|\mathrm{P}| \mathrm{E} \mid$ guidance.

Indexed In: OpenAIRE.

DOI: https://doi.org/10.5281/zenodo.5171575

Google Scholar Citation: IJCSBE

\section{How to Cite this Paper:}

Sonia Lobo \& Ganesh Bhat, S. (2021). Financial Performance Analysis of Motilal Oswal Financial Services Ltd (MOFSL). International Journal of Case Studies in Business, IT, and Education (IJCSBE), 5(2), 50-61. DOI: https://doi.org/10.5281/zenodo.5171575

International Journal of Case Studies in Business, IT and Education (IJCSBE)

A Refereed International Journal of Srinivas University, India.

Crossref DOI : https://doi.org/10.47992/IJCSBE.2581.6942.0119

(C) With Authors.

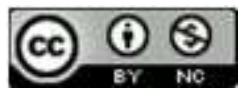

This work is licensed under a Creative Commons Attribution Non-Commercial 4.0 International License subject to proper citation to the publication source of the work.

Disclaimer: The scholarly papers as reviewed and published by the Srinivas Publications (S.P.), India are the views and opinions of their respective authors and are not the views or opinions of the S.P. The S.P. disclaims of any harm or loss caused due to the published content to any party. 


\title{
Financial Performance Analysis of Motilal Oswal Financial Services Ltd (MOFSL)
}

\author{
Sonia Lobo ${ }^{1}$ \& Ganesh Bhat S. $^{2}$ \\ ${ }^{1}$ Research Scholar, College of Management \& Commerce, Srinivas University, Mangalore, \\ India \& Assistant Professor, Department of Humanities, NMAM Institute of Technology, \\ Nitte, India. \\ OrcidID: 0000-0002-8177-8855; E-mail: 1obo14.sonia@gmail.com \\ ${ }^{2}$ Research Professor, College of Management \& Commerce, Srinivas University, Mangalore, \\ India. \\ OrcidID: (0000-0003-1950-8536); E-mail: ganbhatbvr@ rediffmail.com
}

\begin{abstract}
Purpose: Over the last two decades, globalization and technology advancements in financial markets have resulted in a surge of individual investors, granting them improved access to the financial markets. However, the large range of investment avenues available makes the investors' decision-making process more complex. To make investors' lives easier, a stockbroker functions as a liaison between the investor and the stock exchange, allowing them to make more precise investment decisions that are more advantageous for them. Motilal Oswal Financial Services Ltd (MOFSL) is the leading stockbroker firm that offers a wide range of financial services and is the popular choice among Indian investors. To attract new clients and retain the trust of existing customers, the firm needs to maintain a good financial track record. The investment advisor's financial performance helps to a large measure in determining the firm's overall financial health. This paper attempts to analyze the financial performance of Motilal Oswal Financial Services Ltd, for the past three fiscal years i.e., 201819, 2019-20, and 2020-21.

Design/Methodology/Approach: The technique of ratio analysis has been adopted to assess the financial performance of MOFSL using secondary data. Also, the correlation between profitability and efficiency of MOFSL was examined using Pearson correlation. Moreover, SWOC analysis is performed to gain a better understanding of the company's strategic position.
\end{abstract}

Findings/Result: The interpretation of the ratios calculated, given a favorable impression of the financial status of the company and the tested hypothesis of correlation significance has discoursed that there is no significant correlation between profitability and efficiency of MOFSL. Further, the result of the SWOC investigation has offered new insights into the business. It can be concluded from the study that in the FY 2020-21, the company has outperformed in terms of profitability, liquidity, solvency, and efficiency ratios.

Originality/Value: To acknowledge MOFSL's growing popularity in the financial services industry, research was conducted in which the company's financial performance was evaluated using four key financial indicators: profitability, liquidity, solvency, and efficiency ratios.

Paper Type: A case study analysis based on empirical data.

Keywords: Financial Performance, Stockbroker, SWOC Analysis, Ratio Analysis, MOFSL

\section{INTRODUCTION :}

Stockbrokers form a significant part of the country's investment advisory landscape. A stockbroker is a financial market representative, who buys and sells the shares on behalf of clients and is also known as an investment advisor. The brokerage houses (Depository Participant) serve as a mediator between investors and the depository. Two major depositories are operational in India: National Securities Depository Limited (NSDL) and Central Securities Depository Limited (CDSL). Also, in India, the stockbroker has to be enrolled as a member with the concerned exchange such as Bombay Stock 
Exchange (BSE), National Stock Exchange (NSE) and must be registered with the Security and Exchange Board of India (SEBI). The majority of stockbrokers are engaged in the brokerage business and deal with a variety of retail investors and institutional clients. Stockbrokers are normally compensated on a commission basis. A broker with extensive experience and knowledge about the 'ins and outs' of the stock market can assist an investor in making the best decision possible [1]. The broker must provide adequate and right information about the stocks as well as make short-and medium-term investment recommendations to investors, and confirm the purchase and sale of securities rapidly. Most importantly, the broker should be noted for his/her integrity. The broker is required to follow the SEBI's code of conduct. The code of conduct prohibits malpractice and manipulation, as well as expects to abide by the legal obligations. A broker's registration is likely to be suspended if she/he engages in manipulation or price rigging, or if she/he provides false information. If the rules and laws governing insider trading and takeover protocols are not followed, the consequences can be severe. Many investors believe that brokerage firms are to be rated based on their financial success. This article intends to provide a sneak peek into the firm while also attempting to examine financial indicators to comprehend the company's long-term viability and establish MOFSL's profitability performance using ratio analysis. The most commonly used management decision tool/technique for appraising the company's financial statement is ratio analysis. Normally, the company's top executives use the ratio analysis to identify the strength and weaknesses to draw the strategic plan. Also, it is used by the stakeholders to compare the outcomes with that of other organizations, and therefore, it helps to make better investment decisions.

\section{REVIEW OF LITERATURE :}

Researchers have made a significant contribution towards the area of financial performance analysis using various techniques. A review of the literature related to the financial performance analysis of various companies, in general, has been presented below in table 1:

Table 1: Review of Scholarly Articles Related to Financial Performance Analysis

\begin{tabular}{|c|c|c|}
\hline $\begin{array}{l}\text { S. } \\
\text { No. }\end{array}$ & Focus Area & References \\
\hline 1. & $\begin{array}{l}\text { The paper highlights the financial performance of Aditya Birla Stockbroking } \\
\text { Company with the help of ratio analysis. In addition, a t-test was performed. } \\
\text { The result shows that the difference is not significant within the } 10 \text { years for } \\
\text { the working capital turnover ratio, return on total assets, gross profit ratio, and } \\
\text { net profit ratio. }\end{array}$ & [2] \\
\hline 2. & $\begin{array}{l}\text { The paper explores the relationship between financial analysis and accounting. } \\
\text { Also, examines the company's business environment, strategies, financial } \\
\text { status, and performance. This research looks at how financial ratios are used } \\
\text { in financial performance analysis and accounting to help management } \\
\text { comprehend a firm's profitability, financial status, and operating efficiency. }\end{array}$ & [3] \\
\hline 3. & $\begin{array}{l}\text { The paper describes the financial competence of Cadila healthcare and } \\
\text { Sunpharma through the ratio analysis. Various ratios like dividend payout } \\
\text { ratio, quick ratio, return on asset, etc. have been used to analyze the data. It is } \\
\text { found from the study that Sunphama outperformed compared to Cadila } \\
\text { healthcare in most of the aspects of ratio analysis. }\end{array}$ & {$[4]$} \\
\hline 4. & $\begin{array}{l}\text { The paper discussed the financial soundness of two companies Go Digit and } \\
\text { Acko using the CARAMEL model. The term CARAMEL represents capital } \\
\text { adequacy, reinsurance, and actuarial issues, management soundness, earnings } \\
\& \text { profitability. It was revealed in the study that the performance of Go Digit } \\
\text { was better than Acko in most of the measurements. }\end{array}$ & [5] \\
\hline 5. & $\begin{array}{l}\text { The paper explains the significance, various types, techniques, and tools used } \\
\text { in financial analysis. Further, the study assesses the financial performance of } \\
\text { Bambino Agro Industries Limited. The findings suggest that the net current } \\
\text { asset and sundry debtors of the company were increased during the study } \\
\text { period. }\end{array}$ & [6] \\
\hline
\end{tabular}




\begin{tabular}{|c|c|c|}
\hline 6. & $\begin{array}{l}\text { In this paper, the study is carried out on two drug and pharmaceutical } \\
\text { companies KAPL and RDPL listed on BSE. The paper examines the firm's } \\
\text { liquidity, solvency, profitability, and stability. The outcome of the study } \\
\text { discloses that RDPL's debt to net worth ratio declined and as a result financial } \\
\text { stability of the firm dwindled. }\end{array}$ & [7] \\
\hline 7. & $\begin{array}{l}\text { The paper has investigated the financial outcome of Erbil bank. The } \\
\text { profitability ratios such as return generated on the asset, equity returns, and } \\
\text { return generated on deposit were ascertained. According to the findings, the } \\
\text { size of the bank negatively impacted on ROA of the bank. }\end{array}$ & [8] \\
\hline 8. & $\begin{array}{l}\text { A comparative analysis of three listed corporations namely CEU, Malyan, and } \\
\text { FEU related to the education segment in the Philippines was performed. The } \\
\text { liquidity, activity, leverage, and profitability ratios were calculated. Following } \\
\text { a thorough financial ratio examination, FEU was rated most financially sound, } \\
\text { followed by Malayan, and finally CEU. }\end{array}$ & [9] \\
\hline 9. & $\begin{array}{l}\text { A thorough examination of the financial performance of the cement sector has } \\
\text { been carried out. Profitability ratios, asset utilization ratios, and cash } \\
\text { conversion cycles were among the financial ratios used to assess the } \\
\text { performance of the cement industry. }\end{array}$ & [10] \\
\hline 10. & $\begin{array}{l}\text { In this paper, the researcher has developed a model with the help of financial } \\
\text { ratios to predict business failure using the logistic regression technique. The } \\
\text { result indicated that in comparison to non-failed enterprises, failed companies } \\
\text { were highly indebted, inefficient in leveraging assets to create cash flows, and } \\
\text { unable to produce sufficient liquidity. }\end{array}$ & [11] \\
\hline 11. & $\begin{array}{l}\text { The paper attempts to recognize and evaluate the elements influencing the } \\
\text { value of the companies listed in the Indonesian food and beverage unit. The } \\
\text { findings expose that equity return, size of the firm; ownership claims of the } \\
\text { institution, ownership claims of the management, debt-equity ratio, and } \\
\text { company growth all have an impact on the business's value. }\end{array}$ & [12] \\
\hline 12. & $\begin{array}{l}\text { A detailed analysis was carried out to determine the association between } \\
\text { current ratio and profitability, the correlation between acid-test ratio and } \\
\text { profitability also, to assess the relationship between return on capital } \\
\text { employed and profitability. The result disclosed that half of the companies } \\
\text { considered for the study indicated a negative correlation between the current } \\
\text { ratio and the acid test ratio. }\end{array}$ & [13] \\
\hline 13. & $\begin{array}{l}\text { The paper elaborates on how to develop a framework for company-based case } \\
\text { study analysis. The paper expounds on the procedure of doing the case study } \\
\text { analysis which will be valuable to novice and emerging management scholars. }\end{array}$ & [14] \\
\hline 14. & $\begin{array}{l}\text { The technique of multiple regression was utilized to assess the financial } \\
\text { performance of stockbroking companies. The finding suggests that except few } \\
\text { of the stockbroking firms, all other firms undertaken for the study showed a } \\
\text { positive relationship between various financial ratios and net profit. }\end{array}$ & [15] \\
\hline
\end{tabular}

As per the literature review, it is found that while numerous studies have used ratio analysis, none of them have focused on MOFSL's financial performance. Therefore, understanding the growing image and expanding reputation of MOFSL in the financial service sector in India and around the globe, the following study has been undertaken.

\section{OVERVIEW OF MOTILAL OSWAL FINANCIAL SERVICES LTD. (MOFSL) :}

Motilal Oswal Financial Service Ltd (MOFSL) was founded in the year 1987 as a minor sub-broking unit with just two promoters directing the show along with a peon. Mr. Motilal Oswal, who is the present CEO, and Mr. Raamdeo Aggarval, who is the present chairman laid the foundation for the company. MOFSL has positioned itself as a premium stockbroking firm in the country by emphasizing a customer-first philosophy, ethical and responsible business standards, professionalism, strong research- 
based value trading, and ultra-modern technology. In recent times, the company has grown as a multifaceted financial service company with a presence in over 550 cities through 2500 plus business locations, which is managed by over 7000 employees. The company is headquartered in Mumbai, India. In the year 2005, the company stepped into investment banking, followed by the launching of private equity funds in the year 2006. Further, in January 2010, MOFSL established a mutual fund business called Motilal Oswal Asset Management Company (MOAMC). MOFSL also reached a milestone in the year 2013; by setting up Aspire Home Finance Corporation Limited (AHFCL) that offers mortgages for homes, constructions, and extensions in India [16]. MOFSL has bagged many laurels for its excellent service in the financial service sector, which includes the Brand of the year Award at CNBC TV18India Business Leadership Award, Best Performing National Financial Advisor Equity Broker Award in 2012, and many more. A noteworthy fact is that the company featured in Forbes Super 50 Companies in the year 2017. MOFSL has subsidiaries namely: Motilal Oswal Securities Ltd., Motilal Oswal Investment Services, and Motilal Oswal Investment Advisors Pvt Ltd.

\subsection{Products and Services Offered by MOFSL:}

MOFSL offers a diversified array of products and services. The products include investment in Equity, Derivatives, investment in Commodities, Currency investments, IPO'S, Bonds, Fixed Deposits, ME Gold, Portfolio Management Service (PMS), investment in the US equities. Also, the company provides services such as dedicated advisory, Systematic Investment Plan (SIP) through Whatsapp, portfolio restructuring, loan against portfolio, and $24 * 7$ chat services [17]. MOFSL recognizes the demands of its customers and tailors a range of products and services to cater to those demands.

\section{OBJECTIVES :}

MOFSL has expertly steered its customers through their investment journey with over thirty years of experience in the stockbroking industry. The company has successfully created a niche market by deeply resonating through the premium quality of service. In the light of the growing brand image of the company, this study is apt to be undertaken. The study is carried out with the following specific objectives:

1. To perform the SWOC analysis of MOFSL.

2. To analyze the profitability, liquidity, solvency, and efficiency positions of MOFSL.

3. To examine the correlation between profitability and efficiency of MOFSL.

4. To evaluate the financial performance of MOFSL.

\section{RESEARCH METHODOLOGY :}

\subsection{Sources of Data Collection:}

Secondary data was gathered from the company's published annual reports, company's website, and financial websites for this research.

\subsection{Period of Study:}

The study period is for 3 years from 2018-19 to 2020-21.

\subsection{Tools for Data Analysis:}

The study makes use of mainly ratio analysis, which is a relative metric of a company's performance that conveys information about the underlying financial situation. The financial indicators that are embraced to examine the financial status of MOFSL include ratios such as profitability, liquidity, solvency, and efficiency. In addition, a SWOC analysis has been performed to examine the strengths, weaknesses, opportunities, and challenges of the firm.

\subsection{Statement of Hypothesis:}

The following hypothesis is proposed to investigate the relationship between MOFSL's profitability and efficiency:

$\mathrm{H}_{0}$ : There exists no significant correlation between profitability and efficiency of MOFSL.

$\mathrm{H}_{1}$ : There exists no significant correlation between profitability and efficiency of MOFSL.

6. DATA ANALYSIS \& INTERPRETATION : 


\subsection{SWOC Analysis of MOFSL:}

SWOC stands for strengths, weaknesses, opportunities, and challenges. Strengths and weaknesses are internal factors whereas; opportunities and challenges are external variables. SWOC analysis is commonly used as a framework for assessing internal strengths and constraints, as well as identifying potential external opportunities and threats. SWOC analysis is a tool for auditing an organization and its environment [18]-[21]. The detailed analysis of the company's annual report highlights the following strengths, weaknesses, opportunities, and threats.

\section{(1) Strengths:}

Strengths enable a company to achieve its objectives. The following are the strengths of MOFSL:

1. Large and diverse distribution network: The company is having a large and diversified distribution network all over India.

2. Strong research and sales teams: The company is having a good sales team and robust research team to spread its business all over India.

3. Large customer base: The company serves over 19,00,000 plus customers scattered all over the globe, who are happy and satisfied with the quality of the service provided.

4. Brand recognition: MOFSL is the most renowned brand in the stock market, so it will help the company to attract customers. The company has good and experienced top management.

5. Strong financial results: The financial position of the company is good compared to other securities trading companies.

\section{(2) Weaknesses:}

Weaknesses are those hindrances that prevent the firm from accomplishing its mission and achieving its full potential. The weaknesses of the MOFSL are as follows:

1. Penetration is limited to urban areas. The rural areas are oblivious about MOFSL.

2. The trading fees are high compared to other stockbroking companies in the industry.

3. Lack of advertising is causing less awareness among the investors about investment avenues offered by MOFSL.

\section{(3) Opportunities:}

Opportunities are the external conditions that could provide a competitive advantage. Following are the opportunities existing in the market for MOFSL:

1. Growing Financial Services industry's share of disposable income wallet.

2. The huge market opportunity for wealth management service.

3. The wealth management sector is evolving from simply preserving wealth to rapidly enhancing wealth.

4. Reforms in regulation are made easier to enable and aid large participation by all classes of investors.

5. Implementation of Cutting-edge technology to support best practices and processes.

6. The Indian corporate sector's rising desire for growth capital.

\section{(4) Challenges:}

Challenges are the external conditions that could damage the scope of attaining the objectives. Some of the challenges faced by MOFSL are as follows:

1. Execution risk.

2. Global meltdown in liquidity flows.

3. Increased intensity of competition from domestic and international players.

4. Penetration of foreign financial firms in the Indian market.

5. Unfavorable economic conditions of the country will also hinder the company's performance.

6. Strict economic measures imposed by the government and RBI.

\subsection{Ratio Analysis:}

Ratio analysis helps to comprehend the company's financial health. Through ratio analysis valuable inference is drawn regarding a firm's profitability, liquidity, leverage, and growth status. It helps the investors track the financial performance and compare it to that of the competitors. Hence, allowing 
them to make smarter financial decisions. Detailed ratio analysis of MOFSL is conducted using profitability, liquidity, solvency, and efficiency ratios are given as follows:

\section{(1) Profitability Ratio:}

The profitability ratio is used to assess a company's potential to generate income as compared to its expenditures and other costs linked with producing revenue during a given period. Table 2 below indicates various types of profitability ratios used for the study.

Table 2: Types \& Measurement of Profitability Ratios

\begin{tabular}{|l|l|l|}
\hline Parameter & Types & Formula \\
\hline \multirow{3}{*}{ Profitability Ratio } & Gross Profit Ratio (GPR) & GPR = Gross profit / Net sales \\
\cline { 2 - 3 } & Operating Profit Ratio (OPR) & OPR=Operating Profit/Revenue \\
\cline { 2 - 3 } & $\begin{array}{l}\text { Return on Capital Employed Ratio } \\
\text { (ROCE) }\end{array}$ & $\begin{array}{l}\text { ROCE= Net Profit before Interest, Tax } \\
\text { and Dividend/Capital Employed }\end{array}$ \\
\hline
\end{tabular}

(a) Gross Profit Ratio:

The gross profit ratio depicts the relationship between gross profit and total net sales revenue. It is a popularly used tool for evaluating a company's operational accomplishments.

(b) Operating Profit Ratio:

Operating profit margin is a performance ratio that displays the share of profit produced by a company's operations before taxes and interest burdens are deducted.

(c) Return on Capital Employed Ratio:

The association between profit (profit before interest and tax) and capital employed is depicted by return on investment or return on capital employed. Table 3 shows calculated profitability ratios.

Table 3: Profitability Ratios

\begin{tabular}{|l|l|l|l|}
\hline Year & GPR & OPR & ROCE \\
\hline $2018-19$ & 38.31 & 39.79 & 12.40 \\
\hline $2019-20$ & 22.56 & 24.91 & 7.70 \\
\hline $2020-21$ & 47.66 & 49.35 & 18.77 \\
\hline \multicolumn{2}{|l|}{ Source: Published Annual Report [22] \& Moneycontrol [23] } \\
\hline
\end{tabular}

\section{(d) Interpretation:}

There is no ideal standard or norm to comprehend gross profit, operating profit, and return on capital employed ratio. Generally, a higher ratio is considered to be better. The result from the analysis indicates that the company witnessed a higher gross profit ratio of 47.66 in the year 2020-21, compared to the previous financial years. It is a sign that the company has a healthy gross profit margin. The operating profit ratio declined (24.91) in the year 2019-20 compared to the previous year 2018-19. However, there is a sharp rise in the operating profit ratio (49.35) in the year 2020-21 which signifies that the company is in the position of handling the operating cost-efficiently. In addition, the return on capital employed ratio improved in 2020-21 (18.77), demonstrating that the company earns profit more efficiently with its capital.

\section{(2) Liquidity Ratio \& Solvency Ratio:}

Liquidity ratios and solvency ratios are the type of financial metrics that assesses whether a business can repay current debt obligations without any external financial assistance. The solvency ratio focuses on both long-term and short-term financial obligations, whereas liquidity ratios concentrate on a company's short-term financial obligations and current assets. Table 4 shows various types of liquidity ratios and solvency ratios.

Table 4: Types \& Measurement Liquidity and Solvency Ratio

\begin{tabular}{|l|l|l|}
\hline Parameter & Types & Formula \\
\hline Liquidity Ratio & Acid-Test Ratio (ATR) & $\begin{array}{l}\text { ATR= (Current Assets - Inventory) / Current } \\
\text { Liabilities }\end{array}$ \\
\hline
\end{tabular}




\begin{tabular}{|l|ll|l|}
\hline Solvency Ratio & $\begin{array}{l}\text { Debt to Equity Ratio } \\
\text { (DER) }\end{array}$ & DER = Total liabilities / shareholders' equity \\
\cline { 2 - 4 } & $\begin{array}{l}\text { Interest Cover Ratio } \\
\text { (ICR) }\end{array}$ & ICR = EBIT / Interest on long term debt \\
\hline
\end{tabular}

(a) Quick Ratio or Acid-Test Ratio:

The liquidity ratio that assesses a company's presently available liquidity is the quick ratio or acid test ratio. When calculating the quick ratio, easily convertible (in cash) marketable securities and current cash holdings are taken into account. As a result, inventories are not considered when calculating the acid test ratio.

\section{(b) Debt to Equity Ratio:}

One of the most commonly employed debt solvency measures is the debt to equity ratio. It's also known as the $\mathrm{D} / \mathrm{E}$ ratio. It is a vital statistic for determining a company's financial leverage. This ratio determines if the shareholder's equity can satisfy all debts in the event of a business failure.

\section{(c) Interest Cover Ratio:}

The interest coverage ratio is utilized to examine if a corporation can pay interest on its outstanding loan obligations. It's computed by dividing the company's EBIT (earnings before interest and taxes) by the amount of interest due on debts for the accounting period. Table 5 shows various liquidity and solvency ratios.

Table 5: Liquidity and Solvency Ratio

\begin{tabular}{|l|l|l|l|}
\hline Year & ATR & DER & ICR \\
\hline $2018-19$ & 1.38 & 0.55 & 4.77 \\
\hline $2019-20$ & 1.05 & 0.52 & 2.50 \\
\hline $2020-21$ & 1.42 & 0.59 & 8.25 \\
\hline \multicolumn{2}{|l|}{ Source: Published Annual Report [22] \& Moneycontrol [23] } \\
\hline
\end{tabular}

\section{(d) Interpretation:}

The most desirable and optimum value of the quick ratio is $1: 1$. If a company's quick ratio is greater than one, it indicates that the company has more quick assets than current liabilities. As the quick ratio grows the company's liquidity improves. This means, if necessary, more assets can be swiftly transformed into cash. This is wonderful news for investors, but it's even better news for creditors, as they get paid on time. Table 5 reflects that during the study period the company has maintained a quick ratio of above one for all three years. Hence, it results that the company's payoff level and financial health are excellent. Also, if the debt-to-equity ratio is less than one, the company is considered to be prone to less risk than companies with a higher debt-equity ratio. It can be observed from the result that the company has a debt-equity ratio of less than one for the three consecutive years. The company has kept the faith of all its stakeholders upright. The interest coverage ratio is solely concerned with the ability of the company to pay interest on its debt. The lower the ratio signifies the company is more loaded by debt expense. When the company's interest coverage ratio is lower than 1.5 , it means the company is not capable to satisfy its interest obligations. As per the outcome, it can be determined that the company has substantially increased its ICR to 8.25 in the year 2020-21, which is a great indication that the firm will pay off the accrued interest on the debt.

\section{(3) Efficiency Ratio:}

Efficiency ratios are used to evaluate a company's ability to establish income by effectively utilizing its resources, such as capital and assets. The ratios are used to compare expenses to revenues produced effectively that illustrate the amount of revenue or profit a firm can produce from the money it spends to drive its business. The efficiency ratios employed for the study are shown in table 6 .

Table 6: Types \& Measurements of Efficiency Ratio

\begin{tabular}{|l|l|l|}
\hline Parameter & Types & Formula \\
\hline Efficiency & Fixed Asset Turnover Ratio (FATR) & FATR=Net Revenue/Net Fixed Assets \\
\cline { 2 - 4 } Ratio & Account Receivable Turnover Ratio & ARTR=Net Credit Sales/Average Accounts \\
\hline
\end{tabular}




\begin{tabular}{|l|l|l|}
\hline \hline & (ARTR) & Receivables \\
\cline { 2 - 3 } & Total Asset Turnover Ratio (TATR) & TATR=Net Sales/ Average Total Assets \\
\hline
\end{tabular}

\section{(a) Fixed Asset Turnover Ratio:}

Fixed asset turnover ratio is a measure of efficiency. It is also known as return on assets, and it indicates the efficiency with which the firm generates profits from its fixed assets.

(b) Account Receivable Turnover Ratio:

The accounts receivable turnover ratio is also known debtor turnover ratio. This metric estimates number of times average debtors have been turned into cash over the course of a year.

(c) Total Asset Turnover Ratio:

The asset turnover ratio or total asset turnover ratio is a metric that assesses how efficiently a firm utilizes its assets to generate sales. Table 7 below shows various efficiency ratios of MOFSL.

Table 7: Efficiency Ratios

\begin{tabular}{|l|l|l|l|}
\hline Year & FATR & ARTR & TATR \\
\hline $2018-19$ & 2.75 & 1.26 & 0.30 \\
\hline $2019-20$ & 2.61 & 1.52 & 0.30 \\
\hline $2020-21$ & 6.63 & 3.93 & 0.39 \\
\hline \multicolumn{2}{|l|}{ Source: Published Annual Report [22] \& Moneycontrol [23] } \\
\hline
\end{tabular}

\section{(d) Interpretation:}

In the case of the fixed asset turnover ratio, there is no optimum number that is considered as a benchmark for measurement. If the firm has maintained a higher fixed asset turnover ratio, it means the company is using its fixed asset to produce the revenue better. It is evident from the findings that the fixed asset turnover ratio has drastically increased (6.63) in the year 2020-21. This massive increase reveals that the company has efficiently leveraged its assets to produce revenues. Further, a higher accounts receivable turnover ratio suggests a good performance. It is found through the analysis that the company's accounts receivable turnover ratio shot to 3.93 in the year 2020-21, which speaks that the firm is more adequately collecting the debts from its customers. In the perspective of the total asset turnover ratio, a greater ratio is preferable as it implies better use of assets. The company's TATR was consistent in the year 2018-19 \& 2019-20 (0.30) and reached the maximum in the year 2020-21 with 0.39 reflecting that the company has increased its revenue by utilizing its resources more productively.

\subsection{Hypothesis Testing:}

Correlation is a technique used to investigate the relationship between profitability and efficiency of MOFSL. Table 8 below indicates the correlation values between profitability and efficiency ratios of MOFSL. It is found that there is a positive correlation between profitability and efficiency of MOFSL. Gross profit ratio, operating profit, and return on capital employed ratios were highly correlated with fixed asset turnover ratio $(0.8026,0.8151 \& 0.9187$ respectively). However, the sig (2-tailed) P-values of all the observations are more than 0.05 ; it directs there is no significant correlation between profitability and efficiency, hence leading to the acceptance of the null hypothesis $\left(\mathrm{H}_{0}\right)$.

Table 8: Correlation Analysis

\begin{tabular}{|l|l|l|l|l|}
\hline \multirow{2}{*}{} & \multicolumn{4}{|l|}{ Efficiency Ratio } \\
\cline { 2 - 5 } & Particulars & FATR & ARTR & TATR \\
\hline \multirow{3}{*}{$\begin{array}{l}\text { Profitability } \\
\text { Ratio }\end{array}$} & GPR & & & \\
\cline { 2 - 5 } & Pearson Correlation & 0.8026 & 0.7261 & 0.7840 \\
\cline { 2 - 5 } & Sig (2-tailed) & 0.4068 & 0.4827 & 0.4264 \\
\cline { 2 - 5 } & N & 3 & 3 & 3 \\
\hline
\end{tabular}


Source: Calculated at 0.05 level (2-tailed)

\section{FINDINGS :}

The findings of the study are as follows:

(1) The SWOC analysis performed on MOFSL has brought to light enormous strengths that include a good brand image, wider distribution networks, and excellent financial results through which the company can seize the opportunity to conquer the potential market and attract more clients to the customer base. The company is facing minimal weaknesses like not reaching out to the investors in the rural areas and charging a high cost for services offered which has led to facing tough competition from domestic and overseas rivals.

(2) The profitability ratios indicate that the company is having overall sound profitability during the study period.

(3) The study of liquidity and solvency ratios reveals that the company's liquidity and solvency position is good over the study period.

(4) It is evident from the study that the company has maintained a decent efficiency ratio resulting in the generation of more income.

(5) The sig (2-tailed) test has revealed that there is no significant correlation between profitability and efficiency of MOFSL.

(6) The company has stood strong during the volatile year 2020-21 while maintaining the operating parameters.

\section{SUGGESTIONS :}

In light of the above findings the followings suggestions are recommended:

(1) MOFSL should concentrate on expanding its network into rural areas to reach a larger number of customers. They can also shift their focus to greater advertising to promote their products and services.

(2) The company has performed admirably in terms of various financial ratios adopted for the study throughout the study period. To be competitive and succeed in the business, the company must continue to generate strong financial results in the years ahead.

\section{CONCLUSIONS :}

Investing in stock market securities comes with an element of risk. To maximize wealth the investor needs to monitor the market constantly and perform in-depth research. However, this is a daunting task for the common investor. This is where the stockbroker steps in to help the investor by providing valuable investment advice which the investor can capitalize on. The stockbrokers must demonstrate strong financial performance and upright behavior in dealing with the clients keeping in mind the agency and principal relationship. The purpose of this paper was to ascertain MOFSL's financial status during the study period 2018-19 to 2020-21 using ratio analysis. The study period taken for consideration was quite challenging as the Indian economy experienced a downward spiral due to the COVID-19 pandemic. The financial sector experienced a roller coaster ride during this period. Against this backdrop, the study was intended to analyze the financial position of the MOFSL. The analyzed ratios indicate that despite a downturn in the fiscal year 2019-20, the company has weathered the storm and rebounded strongly in the fiscal year 2020-21, achieving excellent results. Presently, the company's overall financial position appears to be very satisfactory. Additionally, SWOC analysis performed has assessed the company's strategic route, emphasizing MOFSL's strengths, weaknesses, opportunities, 
and challenges that in turn helps the investor to understand the business performance of the company better.

\section{REFERENCES :}

[1] Rajkumar, D. K. P., \& Kavitha, N. L. (2015). Relevance of Stock Broking Industry in Capital Market with Special Reference to BSE, Mumbai. International Journal of Latest Technology in Engineering, Management \& Applied Science, 4(10), 42-47.

[2] Sangeetha, C. (2018). Financial Performance of the Aditya Birla Stock Broking Companies. Research Review International Journal of Multidisciplinary, 3(9), 390-392.

[3] Babalola, Y. A., \& Abiola, F. R. (2013). Financial ratio analysis of firms: A tool for decision making. International journal of management sciences, 1(4), 132-137.

[4] Shah, N. K. (2020). Financial Statement Analysis Through Ratio Analysis of Selected Pharmaceutical Companies. GAP Interdisciplinarities, 3(6), 321-331.

[5] Pathak, D. (2020). Financial Soundness of Insurtech Companies in India-An Analysis. International Journal of Case Studies in Business, IT and Education (IJCSBE), 4(2), 203-211.

[6] Bhunia, A., Mukhuti, S. S., \& Roy, S. G. (2011). Financial performance analysis-A case study. Current Research Journal of Social Sciences, 3(3), 269-275.

[7] Ravinder, D., \& Anitha, M. (2013). Financial Analysis-A Study. Journal of Economics and Finance, 2(3), 10-22.

[8] Adam, M. H. M. (2014). Evaluating the Financial Performance of Banks using financial ratios-A Case Study of Erbil Bank for Investment and Finance. European Journal of Accounting Auditing and Finance Research, 2(6), 162-177.

[9] Tugas, F. C. (2012). A Comparative Analysis of the Financial Ratios of Listed Firms Belonging to the Education Subsector in the Philippines for the Years 2009-2011. International Journal of Business and Social Science, 3(21), 173-190.

[10] Naz, F., Ijaz, F., \& Naqvi, F. (2016). Financial performance of firms: evidence from Pakistan Cement Industry. Journal of Teaching and Education, 5(01), 81-94.

[11] Lakshan, A. I., \& Wijekoon, W. M. H. N. (2014). The use of financial ratios in predicting corporate failure in Sri Lanka. GSTF Journal on Business Review (GBR), 2(4), 37-43.

[12] Mahzura, T. A. S. (2018). The Analysis of The Influence of Financial Performance, Company Size, Ownership Structure, Leverage and Company Growth on Company Values in Food and Beverage Listed in IDX 2012-2016 Period. International Journal of Public Budgeting, Accounting, and Finance, 1(4), 1-12.

[13] Ehiedu, V. C. (2014). The impact of liquidity on profitability of some selected companies: The financial statement analysis (FSA) approach. Research Journal of Finance and Accounting, 5(5), 81-90.

[14] Aithal, P. S. (2017). Company Analysis-The Beginning Step for Scholarly Research. International Journal of Case Studies in Business, IT and Education (IJCSBE), 1(1), 1-18.

[15] Sangeetha, C. Analysis (2018). Financial Performance of a Stock Broking Companies using Multiple Regression. Research Review International Journal of Multidisciplinary, 3(11), 629-633.

[16] https://en.wikipedia.org/w/index.php?title=Motilal_Oswal_Financial_Services\&oldid=10177453 95 retrieved on 02.06.21.

[17] https://www.motilaloswal.com/retrived on 02.06.21.

[18] Aithal, P., \& Kumar, P. (2015). Applying SWOC Analysis to an Institution of Higher Education. International Journal of Management, IT and Engineering, 5(7), 231-247.

[19] Gurel, E., \& Tat, M. (2017). SWOT analysis: a theoretical review. Journal of International Social 
Research, 10(51), 994-1006.

[20] Vlados, C. (2019). On a correlative and evolutionary SWOT analysis. Journal of Strategy and Management, 12(3), 347-363.

[21] Ghazinoory, S., Esmail Zadeh, A., \& Memariani, A. (2007). Fuzzy SWOT analysis. Journal of Intelligent \& Fuzzy Systems, 18(1), 99-108.

[22] https://www.motilaloswalgroup.com/Investor-Relations/Financial-Report/Annual retrieved on 21.06.21.

[23] https://www.moneycontrol.com/stocks/company_info/print_main.php retrieved on 21.06.21.

$* * * * * * * * * * * *$ 